\title{
Funkjonowanie pojęcia "pan" w kulturze wiejskiej Królestwa Polskiego końca XIX w.
}

Celem artykułu jest próba rekonsktrukcji pojęcia "pan”, jakie ukształtowało się i funkcjonowało w wyobraźni środowiska wiejskiego pod koniec XIX w. Podstawą do badań są: listy chłopów-emigrantów do Brazylii i Stanów Zjednoczonych z lat 1890-18911, korespondencja ukazująca się na łamach czasopisma "Gazeta Świąteczna" wydawanego w Warszawie od 1881 r., pamiętniki chłopskie oraz dane etnograficzne zebrane na ziemiach Królestwa Polskiego na przełomie XIX-XX w.

Należy zwrócić uwagę, że wśród wymienionych listów wykorzystano trzy oryginalne kolekcje. Kolekcję listów emigrantów do Brazylii i Stanów Zjednoczonych stanowi korespondencja zatrzymana przez wydział walki z agentami emigracyjnymi Kancelarii Ober-Policmajstra Warszawskiego, którą przechowywano w Archiwum Akt Dawnych w Warszawie². Większa część zespołu zaginęła podczas powstania warszawskiego. Przypadkiem zachowało się ponad 300 listów z lat dziewięćdziesiątych XIX w., które były opracowane i wydane przez Witolda Kulę i jego najbliższą rodzinę w 1973 r.

Przetrwały również pochodzące z późniejszego okresu listy do „Gazety Świątecznej", przechowywane w Bibliotece Narodowej w Warszawie ${ }^{3}$. 21 listów z tej kolekcji opracowała i wydała w 1978 r. francuska badaczka

${ }^{1}$ Listy emigrantów z Brazylii i Stanów Zjednoczonych 1890-1891, do druku podali, wstępem opatrzyli W. Kula, N. Assorodobraj-Kula, M. Kula. Warszawa 1973.

2 Kontrola korespondencji zagranicznej mieszkańców Królestwa Polskiego została wprowadzona przez władze rosyjskie $\mathrm{w}$ ramach walki z emigracją $\mathrm{w}$ listopadzie $1890 \mathrm{r}$.

${ }^{3}$ Biblioteka Narodowa w Warszawie. Dział rękopisów (dalej: BN), Listy czytelników do redakcji „Gazety Świątecznej”, sygn. II 5978; IV 5979; IV 5967. 
Céline Francelle-Gervais ${ }^{4}$. Oprócz tego w Państwowym Archiwum Federacji Rosyjskiej w Moskwie w zespole „Dowody Rzeczowe” przechowywany jest unikatowy zbiór listów do tygodnika ludowego "Zaranie” z lat 1909-19155.

Wymienione listy można zaliczyć do rodzaju źródeł o charakterze mówiono-pisanym. W tym przypadku pojęcie mówiono-pisany jest wykorzystywane dosyć szeroko zgodnie z pojmowaniem tekstu ustnego i tekstu pisanego przez rosyjską badaczkę Swietłanę Tołstoj. Zwraca ona uwagę na to, iż „przy określeniu pojęcia tekst ustny należy wychodzić nie z opozycji binarnej tekst ustny - tekst pisemny, która zakłada jednoznaczną kwalifikację każdego konkretnego tekstu jako ustnego lub pisanego, a z określenia skali »ustności«, którą buduje się pomiędzy biegunem »ustny « (umownie tekst języka mówionego) i biegunem "pisemny « (umownie tekst literacki)"6. Tak szeroko pojmowaną opozycję pomiędzy tekstem ustnym a tekstem pisanym przyjmuje ona dla całej kultury i uważa za podstawową kategorię ${ }^{7}$. Do źródeł mówiono-pisanych można więc zaliczyć zarówno materiał folklorystyczny, jak i listy oraz wspomnienia chłopów. Tym bardziej, że w badanym okresie listy pisano często pod dyktando, tj. „na głos”, i odczytywano za pomocą „uczonego", „pisennika” lub „tłumacza”. Ci, którzy nauczyli się nie tylko czytać, ale i pisać, podkreślali: „uczonego nie prosiłem do pisania, jak umiem tak napisałem swoio renko" ${ }^{\prime}$. Chociaż zdarzało się, że czytelnicy prasy ludowej niejednokrotnie przyznawali, że list nie był napisany własnoręcznie. Jeden z chłopów donosił: "Jeżeli ten list zasługuje na wydrukowanie w Gazecie, to proszę go w niej umieścić. Sam pisać nie umiem, więc prosiłem moją żonę, aby to wszystko napisała i za mnie podpisała" 9 .

Pojęcie „pan” wykorzystywano do określenia sytuacji nietypowych dla życia wiejskiego, zazwyczaj do przedstawienia zjawisk związanych z marzeniami, wychodzącymi za ramy osiągalności. Realizacja podobnego marzenia była ekwiwalentem przekształcenia się w pana/szlachcica. Przy czym panem można było zostać nie w pełni, a osiągnąć jedną z charakterystycz-

${ }^{4}$ C. Francelle-Gervais, "Oto zasyłam opisanie całego mojego życia..." (Listy przedptatników "Gazety Światecznej" do Promyka), „Regiony” 1978, nr 4, s. 76-102.

${ }^{5}$ Государственный архив Российской Федерации, фонд 1167, опись 1, единица хранения 1487-1849. Zob. opis kolekcji: M. Krisań, Listy do gazety „Zaranie” z lat 1909-1915, „Dzieje Najnowsze" 1998, nr 4, s. 22-28.

${ }^{6}$ С. Толстая, Устный текст в языке и культуре, w: Tekst ustny: struktura i pragmatyka problemy systematyki - ustność w literaturze, red. M. Abramowicz i J. Bartmiński, Wrocław 1989, s. 11.

7 Tamże, s. 14.

${ }^{8}$ List nr 19 (Czytelnik Antoni Hukaluk, Ze wsi Szustka gminy Szustka w powiecie radzyńskim guberni siedleckiej, brak daty), [w:] C. Francelle-Gervais, „Oto zasytam...", s. 99.

${ }^{9}$ M. Strychalska, Ze wsi Krętowa w powiecie radomskim, guberni piotrkowskiej, „Gazeta Świąteczna" 1889, nr 429, s. 6. Więcej na ten temat zob. M. Krisań, Chłopi wobec zmian cywilizacyjnych w Królestwie Polskim w drugiej potowie XIX - początkach XX w., Warszawa 2008, s. 58-65. 
nych dla wizerunku pana oznak. Stanisław Czernik podkreśla, że „interesującą osobliwością poezji ludowej jest oryginalny »chwyt« poetycki polegający na wprowadzeniu motywu symbolicznego, po czym bezpośrednio następuje wytłumaczenie, co on właściwie znaczy"10. Tę samą tendencję do wykorzystania "symboli wytłumaczonych" znajdujemy i w listach przy użyciu pojęcia "pan”, kiedy owo pojęcie nie pojawia się samodzielnie, lecz w połączeniu z dodatkowym określeniem, które łłumaczy, na czym polega porównanie. Np. emigrant do Brazylii Marcin Knaczeński, wymieniając wszystkich krewnych na początku listu, donosił: „że sobie żyje jak Pankossky i niewjem co to jest bieda, życie sobie prowadzie kralieske [królewskie], wina tile co w Polsce wody i wudky i wszelkych tronkuw"11. Autor listu porównuje siebie do Pana Koskiego. Inny chłop w Brazylii oznajmiał, ,że tilio drzewa mam jak pan Mostoski"12. Wydaje się, że wspomniane tu nazwiska należą do bohaterów bajek i legend. W folklorze ukraińskim do tej pory funkcjonuje bajka Pan Kocki z następującym wątkiem. Kota, który nie polował na myszy, wyganiają z domu. Idzie do lasu, gdzie spotyka lisicę. Lisica przedstawia go mieszkańcom lasu jako straszne zwierzę, któremu należy składać daninę w zamian za ciszę i spokój w lesie. Dzięki temu Pan Kocki całe dnie leniuchuje, nie wie, co to jest bieda, i prowadzi królewskie życie. Określenie „Pan Kocki” jest stosowane wobec ludzi umiejących sobie radzić w życiu w ten sam sposób, jak bohater bajki. W tym przypadku porównanie swego życia do życia „Pana Kockiego" służy przedstawieniu marzenia o łatwym życiu.

Pojęcie "pan" miało tak pozytywne, jak i negatywne konotacje - wszytko zależało od sytuacji społeczno-komunikacyjnej. Np. w badanym okresie zaczął zmieniać się stosunek do czystości mieszkań, jednak jedna z kruszynianek skarżyła się w "Zaraniu”, że za to, iż utrzymuje czystość i porządek w domu, mówią na wsi, że przerobiła się „na szlachciankę"13. Jan Słomka mieszkający w Galicji tuż przy granicy z Królestwem wspominał, że na wsi zamiast zegara w każdym domu trzymano koguta, jednak jemu ,już na początku gospodorowania uprzykrzyło się to wychodzenie w zimie na dwór i śledzenie po gwiazdach, jak prędko wstać; kogut nieraz się pomylił, bo zapiał na północek, a myślało się, że to już drugie lub trzecie pianie". Postanowił kupić zegar, jednak żeby się nie narazić, zdecydował ukryć go przed sąsiadami: „Rzecz jednak zaraz się wydała... Powoli przychodzili starsi sąsiedzi, oglądali zegar i dziwili się, że mogłem wydać aż 4 reńskie, a ten i ów przygadywał, że bawię się

10 S. Czernik, Stare złoto, Warszawa 1962, s. 284.

${ }^{11}$ List nr 45 (Marcin Knaczeński z Silveiro Martinho, Rio Grande do Sul do nieznanego adresata. 6 IV 1891), [w:] Listy emigrantów, s. 183. Tu i dalej przy cytowaniu zachowuje się pisowia oryginału.

${ }^{12}$ List nr 62 (Jan Sitniewski z Santa Candida Santa Theresa (?), Rio Grande do Sul do Franciszka Bagińskiego, Stara Wieś, powiat przasnyski, 13 III 1891), tamże, s. 207.

${ }^{13}$ L. Kruszynianka, Zpod Leoncina, "Zaranie” 1912, nr 52, s. 1319. 
w »pana «"14. Szczepan Ciekot wspominał, że „noży i widelców nigdy w tym okresie nie używaliśmy, nawet na weselu lub chrzcinach nie było noży lub widelców. Mówiono, że »to pański wymysł"15. Pojęcie „pan” obejmowało w świadomości chłopów gospodarstwo, jedzenie, ubiór, zachowanie się, sposób spędzania czasu wolnego.

Bycie panem mogło oznaczać posiadanie dużego gospodarstwa, które było podstawą szeroko pojmowanej stabilności. Marcin Knaczeński donosił swojemu szwagrowi: „Proszę cię przyjeżdziaj ze swoju żonu i dziećmy do nas, bo jest dobrze, bo ja sobie żyje jak pan u waz w Polsce, ktury posiada kylka folwarkuw"16. Z kolei Antoni Zieliński pisał do braci: „Mówili ludzie, że w Brazeli nie ma bydła, koni, ani nic, a tam fszystko jest, bydło, konie, ofce, nawet kozy są, tak samo jak w Polsce. Moi mili bracia, jusz ja by sie z wami nie mijał na wasze gospodarstwo. Teras ja jesdem Pan, to nie tak jak w Polsce było"17.

Pojęcie "pan” miało charakter znakowy. Chłop starał się podtrzymywać swój status poprzez posiadanie nieruchomości, a kiedy było to niemożliwe, odwoływał się do innych rodzajów własności, takich jak, np. odzież, określanych przez socjologów Williama Thomasa i Floriana Znanieckiego jako „wtórne rodzaje własności”. Do tej pory funkcjonuje przysłowie: „poznać pana po cholewach". Jeden z czytelników z guberni warszawskiej pisał do "Gazety Świątecznej” o przyczynach zaniku ubioru tradycyjnego na wsi: „Ale jest jeszcze jeden, śmieszny i grzeszny powód wyrzekania się ojcowitego ubioru. Powód ten, to głupia obawa, że jakby przywdział kujawską długą sukmanę, za którą zapłacił około 20 rubli, to by mu żaden mieszczuk nie mówił »panie«. A jak się ubierzy w kurtkę, w buty bez cholew, w kapelusz przerzętny na dwie połowy z piórem $w$ tyle, to wtedy dopiero wysoki! To dopiero w mieście lub w innej parafji na odpuście jest »panem «! Ogląda się jednak, czy niema kogo ze znajomych, co by mógł go wydać, że na wsi pasa świnie, bydło, gęsi. A co mowy - to i słuchać zabawnie, kiedy taki pokrętny Kujawiak rozmawia z Żydem lub z jakim mieszczaninem. Jak zacznie powtarzać »jo!jo!jo!«, a tam, gdzie wypada o, wymawiać a, to choć jest tylko półgłupkiem, wydaje się całkiem głupi"18. Jak wspomina Aleksander Bogusławski, młodzi chłopi „od przebrania się zaczynali swój pobyt w mieście. Starali się jak najprędzej na to zarobić, aby przyjechawszy na wieś imponować tym ubraniem

14 J. Słomka, Pamiętnik włościanina od pańszczyzny do dni dzisiejszych, Tarnobrzeg 1994, s. 18.

15 S. Ciekot, Wspomnienia 1885-1964, Warszawa 1969, s. 55.

${ }^{16}$ List nr 44, s. 183.

${ }^{17}$ List nr 77 (Antoni Zieliński z Sao Antonio da Patrulha, Rio Grandę do Sul do Mikołaja Bamy (adres nieznany; poczta Ciechanów). 26.02.1891), [w:] Listy emigrantów, s. 227.

18 Czytelnik, Z pod Brześcia-Kujawskiego w guberni warszawskiej, „Gazeta Świąteczna” 1898, nr 907, s. 6. 
swoim rówieśnikom”19. Czytelnicy z powiatów janowskiego i biłgorajskiego guberni lubelskiej w latach 1891 i 1910 pisali: „młodym ludziom zachciało się »pańskować«. Zamiast dawnych ładnych sukman ojców, synowie stroją się teraz w jakieś kurtki krótkie, w których teraz są podobniejsi do diabłów niż do ludzi. Parcianki też białe zamieniają na jakieś barchowe jubki” 20 ; „młodym chłopakom lepiej się podoba »leciste« ubranie; zaczynają się już ubierać $\mathrm{w}$ »cejkowe« kamizelki i spodnie, i w buty na niskich obcasach z ostremi nosami"21.

Kultura miejska w świadomości wiejskiej była ekwiwalentem kultury szlacheckiej: żeby zostać panem wystarczyło „zrzucić sukmanę, a kupić szlafrok niemiecki" ${ }^{22}$. Czytelnik z guberni kieleckiej donosił: „,jak przyjdzie niedziela, jak się postroją, wtedy co na którego spojrzysz, to zdaje się hrabia i hrabina. Mężczyźni pozapuszczali takie baki, jak dawniej nosił hrabia, a jak się zbiorą pod kościołem, to niektórzy tylko się po tych bakach głaskają"23. N.N. z guberni kaliskiej skarżył się: „Kobiety nasze także nie takie, jak były przedtem. Każda dumna i pyszna, nie zna dawnej swej przyjaciółki lub koleżanki, a gdy pozawiesza na sobie falbany i pióra do kapelusza, to pcha się na sam przód w kościele, aby być pierwsza, aby wszyscy widzieli, jak się pióra wiewają, jak się suknia lśni; a każda wyperfumowana, wypomadowana, że aż się mdło robi. Ale taka już moda"24. Dodajmy, że w badanym okresie ubiór świąteczny dopełniały: chusteczka do nosa, rękawiczki, laseczka, parasolka i oczywiście zegarek.

Dobre jedzenie było $\mathrm{w}$ pojmowaniu chłopów jednym z podstawowych elementów dobrego życia pańskiego. Jeden z emigrantów w następujący sposób prosił o rękę: „A ja terasz proszę pani niech poni nie będzie zły woli na mię i niech pozwoli jechać pannie Aleksandrze do Ameryki, to ja bym zarasz wysłał szyfkartę, po panią i bym się radł ożenić z panią w Ameryce, bo może sobie pani zauważyć, ze ja zarabiam na dziesić godzin dular i pół, a na polskie to są trzy ruble, to można sobie żyć lepiej jak w Polsce pan byle jaki, bo co ja ziem w każdy dzień to żaden człowiek w Polsce nie zi [zje] tego w duże

19 A. Bogusławski, Czytelnicy "Gazety Światecznej" i "Zorzy” oraz innych czasopism w gminie Woźniki powiatu piotrkowskiego w okresie 1900-1907 r. na tle stosunków społeczno-gospodarczych $i$ kulturowych okręgu, Zakład Historii Ruchu Ludowego Archiwum przy NK ZSL (ZHRLA), 0-70. K. 61 (1961).

${ }^{20}$ F. Ożarowski, Wieś Krzemień w powiecie janowskim, guberni lubelskiej, „Gazeta Świąteczna” 1891, nr 539, s. 3.

${ }^{21}$ K.D., Ze wsi Przymiarek w powiecie biłgorajskim, guberni lubelskiej, "Gazeta Świąteczna” 1901, nr 1053, s. 6-7.

22 J. Maj, Ze wsi Babina w powiecie lubelskim, „Gazeta Świąteczna” 1897, nr 835, s. 7.

${ }^{23}$ J.B., Z Chrzastowa w powiecie włoszczowskim, guberni kieleckiej, "Gazeta Świąteczna” 1894, nr 720 , s. 6.

${ }^{24}$ N.N., Ze wsi Grodźca, w powiecie stupieckim guberni kaliskiej, "Gazeta Świąteczna” 1887, nr 313, s. 6-7. 
święta” 25. Józef Filipowski donosił w "Gazecie Świątecznej”, że „gospodarze posprzedawali grunta starych ojców, przyszli do Łodzi, żeby od razu przerobić się na panów. Już im nie smakował groch, chleb i kasza; zaczęli jeść mięso, bułki, pić kawę, i tak roztrwonili pieniądzę"26. Nie jest przypadkową opozycja, jaką widać w liście ostatniego autora, a mianowicie przeciwstawienie groch - mięso, chleb - bułki, kasza - kawa. Jeszcze w pierwszej połowie XIX w. odżywianie było głodowe, poprawa nastąpiła dopiero pod koniec lat osiemdziesiątych XIX w. dzięki ziemnakom oraz innym roślinom okopowym. Na przełomie XIX i XX w. pożywienie nosiło wybitnie roślinny charakter, ważne miejsce zajmowały w nim kasze ${ }^{27}$. Np. w powiecie zamojskim guberni lubelskiej chłopi pod koniec lat siedemdziesiątych XIX w. jedli barszcz robiony z mąki żytnej, kapustę z grochem, kartofle, chleb gruby żytni mieszany z jęczmieniem, kaszę tatarczaną i kluski. Mięso należało do rzadkości, używali go, gdy raz lub dwa razy do roku bili u siebie wieprze, dla okrasy ${ }^{28}$. Kazimierz Janikowski w liście do „Gazety Świątecznej” podał szczegółowy opis pożywienia chłopów powiatu biłgorajskiego guberni lubelskiej, podstawą którego były ziemniaki i kapusta, rzadko używano słoniny, sadła i omasty, mięso należało do "rzadkiego zbytku" ${ }^{29}$.

Dobre pożywienie było powodem do chluby. Jan Jaszczeński w następujący sposób opisywał, jakie dostaje jedzenie: „Alie bracie, kochany szostunku, napiszię ci parę słuw o Ameryczie, jakie życie mamy dobre. Mięszio lub kiełbasa do tiego przanny chłyb, kawa lub cherbata, a do tego rozmaiyte słodtkie ciastka, to iy ty będzies używał razem z namy ty słodyczy, bo mię to już się przy jadły" ${ }^{\prime 30}$. Franciszek Skurczyński w liście z Brazylii donosił o czterech posiłkach dziennie, dodając, że „mięsa mamy pod dostatek" ${ }^{31}$. Dobre wyży-

${ }^{25}$ List nr 195 (B.B. z Cleveland, Ohio, Stany Zjednoczone, do niejakich Karbowskich (adres nieznany). Brak daty. Oryginat nie istnieje. Przedruk z odpisu wykonanego w czasie okupacji przez stuchaczy tajnej Wolnej Wszechnicy Polskiej w Warszawie), [w:] Listy emigrantów, s. 364.

${ }^{26}$ J. Filipiński, Z miasta Łodzi, w guberni piotrkowskiej, "Gazeta Świąteczna" 1885, nr 217, s. 5.

27 A. Kowalska-Lewicka, Z. Szromba-Rysowa, Pożywienie, [w:] Etnografia Polski. Przemiany kultury ludowej, t. 1, red. M. Biernarcka. Wrocław [etc.] 1976, s. 355-356; T. Sobczak, Przełom w konsumpcji spożywczej w Królestwie Polskim w XIX wieku, Wrocław [etc.] 1968, s. 253-255.

28 Opis gospodarstwa cząstkowego włościańskiego we wsi Tworzyciowie guberni lubelskiej, powiatu zamojskiego, gmina Sułów, będącego własnościa Wawrzyńca Knapa, [w:] Encyklopedia rolnictwa i wiadomości związek z niej mających, red. J.T. Lubomirski, E. Stawiski, S. Przystyński, przy współudziale L. Krasińskiego, L. Kronenberga, J. Zamojskiego, t. II, D-G, Warszawa 1874, s. 1051.

${ }^{29}$ K. Janikowska, Zpod Józefowa Ordynackiego w powiecie biłgorajskim, guberni lubelskiej, „Gazeta Świąteczna” 1887, nr 353, s. 6.

${ }^{30}$ List nr 125 (Jan Jaszczeński z Grand Rapids, Mich. do siostrzeńca (adres nieznany), 17 I 1891. Wyjątkowo zła pisownia), [w:] Listy emigrantów, s. 277.

${ }^{31}$ List nr 64 (Franciszek Skurczyński z Rio Negro, Parana do brata (adres nieznany), 31 III 1891, oryginat nie istnieje, przedruk z odpisu wykonanego w czasie okupacji przez stuchaczy tajnej Wolnej Wszechnicy Polskiej w Warszawie), tamże, s. 210. 
wienie przewidywało częste posiłki, które składały się z mięsa, chleba, słodyczy, kawy, herbaty i alkoholu.

Nieodłącznym elementem wizerunku pana w środowisku wiejskim było pijaństwo.

Nie dbam ja o złoto,

przepiję z ochotą.

A niedbam i o kontusze,

to mi głowy, łba nie suszy.

Otóż to ja pan,

Co o nic nie $\mathrm{dbam}^{32}$.

W XIX w. chłopi zaczęli przechodzić na wysokoprocentowe trunki. Pijaństwo na wsi stało plagą. Przyczyny przejścia na alkohol wysokoprocentowy kryły się w rozpoczęciu użycia do jego produkcji ziemniaków, obniżeniu ceny oraz w funkcjownowaniu na wsi stereotypowego wizerunka o dogodnym życiu ${ }^{33}$. Alkohol jakby dawał możliwość zasmakowania „pańskiego życia”. Jeszcze pozostały w pamięci wiejskiej opowieści o tym, jak hulała szlachta w XVII i XVIII w. ${ }^{34} \mathrm{~W}$ badanym okresie wieśniacy pili otwarcie, tak by inni widzieli, że ich na to stać, pili na hulankach, przede wszystkim w karczmach i szynkach, co samo w sobie było już atrakcją. Nietórzy chłopi zamiast iść w niedzielę do kościoła zawracali do szynku, w którym spędzali cały dzień. Księża walczyli z pijaństwem i nawoływali, „aby karczmę omijać, jak przystało na dobrych katolików" ${ }^{\prime 35}$. Jeśli to nie skutkowało, to często imiona grzeszników wygłaszano z ambony, było to też pewną rozrywką. Jak pisał Małkiewicz: „Na kazaniu też nikomu się spać nie chce, bo jest czego posłuchać, a najbardziej słuchają pijacy, czy nazwisko którego z nich nie będzie wygłoszone na ambonie" 36 .

Pojęcie „pan” obejmowało również sposób spędzania czasu wolnego. Jeden z czytelników "Gazety Świątecznej” pisał o miejscowej młodzieży: „Pracy po większej części się wstydzą. Każdy prawie przeradza się w jakiegoś panka i zdaje mu się, że pracować nie powinien” 37 . W listach do „Gazety

32 O. Kolberg, Dzieła wszystkie, t. XXVII, Mazowsze, cz. IV, Wrocław-Poznań 1964, s. 329.

33 B. Baranowski, Początki i rozpowszechnienie uprawy ziemniaków na ziemiach środkowej Polski, Łódź 1960, s. 57.

${ }^{34}$ Zob. Z. Kuchowicz, Obyczaje staropolskie XVII-XVIII wieku, Łódź 1975, s. 61.

35 Jan K., Ze wsi Bargłowa w powiecie augustowskim, guberni suwalskiej, „Gazeta Świąteczna” 1913 , nr 1711, s. 7.

${ }^{36}$ J. Małkiewicz, Z parafii Glinojeckiej, powiatu ciechanowskiego, guberni płockiej, „,Gazeta Świąteczna" 1885, nr 242, s. 5.

${ }^{37}$ Mieszkaniec powiatu będzińskiego, Z pod Dąbrowy Górniczej, „,Gazeta Świąteczna” 1895, nr 731, s. 6. 
Świątecznej" dość często pojawia się informacja o młodzieży, która gardzi pracą na wsi, ponieważ w fabryce lub podczas prac sezonowych w Prusach można otrzymać większe wynagrodzenie. Ważną częścią spędzania czasu wolnego były nie tylko obecność na nabożeństwie w kościele, na chrzcinach, ślubie, ale też wyjazdy na targ lub jarmark. Podróż do miasta, na targ była ważna również ze społeczngo punktu widzenia. Ładnie ubrany chłop z żoną jechał nie tylko żeby sprzedać towar, lecz również żeby popisać się swoim dostatkiem. Bohdan Baranowski zwraca uwagę na to, że „ekonomiści i publicyści XIX i pocz. XX w. z oburzeniem pisali o tym marnotrawstwie czasu, o tych bezproduktywnych i zbyt częstych wyjazdach do miasta" ${ }^{\prime 38}$. Ale nowy styl życia zobowiązywał do tego, by coraz częściej pokazywać się wśród ludzi.

W jednej z piosenek chłopiec pyta się dziewczyny:

A ty, dziewczyno, wiele o mnie wiesz,

ja ci się kłaniam, a ty nie spojrzysz;

Czym to ja kaleka,

Czym nie mam konika,

Czego ze mnie chcesz? ${ }^{39}$

Konie były ważnym elemenem wizerunku pana, podkreślały status człowieka. Chłop Ignacy Galinowski z Brazylii donosił: „Kumotsze Galasieski mam liepsze ctery konie jak kumoter w pańske jeździ" ${ }^{40}$. Mając konie, można było myśleć o korzystniejszych mariażach dla swoich dzieci bądź ubiegać się o urząd sołtysa lub wójta. Baranowski uważa, że zamiana wołów na konie $w$ gospodarstwie wiejskim miała tak ekonomiczne, jak i społeczne ugruntowanie. Po zniesieniu pańszczyzny chłopi zaczęli naśladować formy życia towarzyskiego drobnej szlachty. Bogaty chłop koniecznie musiał jechać do kościoła lub do miasta końmi, a nie wołami ${ }^{41}$.

Pojęcie "pan” było związane z określonym sposobem zachowania. Jeden z abonentów "Gazety Świątecznej” pisał o takiej młodzieży w 1896 r.: „Młokososu, pewny siebie, nasunie kapelusz albo czapkę na ucho, papieros weźmie w zęby, głowę zadrze do góry, zdawałoby się, że wśród najpiększego południa pilnie gwiazdy liczy, nikogo nie pozdrowi, przed nikim Pana Boga nie pochwali. Niech wszyscy wiedzą, że o nikogo nie dba; nie darmo przecież był w Dąbrowie, kupił sobie buty z mosiężnemi podkówkami, czarny ka-

38 B. Baranowski, Podstawowa siła pociagowa dawnego rolnictwa w Polsce, Wrocław [etc.] 1966, s. 55.

${ }^{39}$ A. Petrow, Lud ziemi Dobrzyńskiej, „Zbiór wiadomości do antropologii krajowej” 1878, t. 2, s. 54 .

${ }^{40}$ List nr 43 (Ignacy Kalinowski z Iyuhy, Rio Grande do Sul do Ferdynanda Schultza (adres nie ustalony), 6 III 1891), [w:] Listy emigrantów, s. 181.

41 B. Baranowski, Podstawowa siła pociagowa, s. 53. 
ftan czy jaki surdut, kapelusz, parasol i kalosze, ojciec i matka cieszą się, że ich syn wykierował się w owej Dąbrowie na takiego pana"42. Czytelnik z guberni piotrkowskiej pisał: „A gdy na siebie wdzieje niemiecką kurtkę, żydowską czapkę, babskie trzewiki i zabawkę za 2 ruble, uważaną niby za zegarek, to taka pycha go w tym stroju opanuje, jakby on był czymś lepszem od innych wieśniaków" ${ }^{\prime 3}$. Właśnie tę pychę należało podkreślić nie tylko ubiorem, ale i sposobem zachowania. Jeden z mieszczan z guberni warszawskiej z oburzeniem pisał, że „najuboższa pragnie naśladować najbogatszą i w stroju i w zachowaniu się" ${ }^{44}$. Można było nie ucisnąć reki gospodarza w siermiędze ${ }^{45}$, nie zdjąć na znak przywitania czapki lub kapelusza: „Pierwszy-lepszy młokosos, byle się dostał do fabryki, zaraz tak zhardzieje, że przy spotkaniu ze starszym nawet Boga nie pochwali. Bo i jakże by Go zresztą pochwalił? Musiałby przytem zdjąć czapkę, a przecież nie po to tak modnie uczesał czuprynę, żeby ją potargać. Oj nie, on czapkę włożył w domu przed lusterkiem i bez koniecznej potrzeby nie zdejmie jej na ulicy" 46 .

Chłopi, którzy chcieli podkreślić swój status, naśladowali sposób mówienia, charakterystyczny dla kultury szlacheckiej i/lub miejskiej, co współcześni określali jako "mówienie z pańska" 47 . Jan Nawrocki - opisując modne dziewczęta z guberni suwalskiej - odnotowywał: „A jak z kim rozmawia, chce mówić po pańsku, a tyle rozumie... co owca z Gdańsku" ${ }^{48}$. Starym i wypróbowanym sposobem, by poprawić swój status, była zmiana nazwiska za pomocą końcówki. W taki to sposób chłop Jan Król stawal się Janem Królikowskim ${ }^{49}$.

Przedstawiony $\mathrm{w}$ tym artykule na materiale źródeł mówiono-pisanych wizerunek „pana” funkcjonujący w kulturze wiejskiej Królestwa Polskiego końca XIX w. jest przykładem wykorzystania podobnych materiałów przy badaniu historii społecznej, gdzie ważne miejsce zajmuje próba rekonstrukcji funkcjonujących stereotypów oraz ich wpływ na przyjmowanie nowoś-

42 Przedpłatnik, Ze wsi Złotej w powiecie pińczowskim, guberni kieleckiej, „,Gazeta Świąteczna” 1896, nr 820, s. 6.

43 Mieszkaniec powiatu będzińskiego, Z pod Dąbrowy Górniczej, "Gazeta Świąteczna” 1895, nr 731, s. 6.

44 Mieszczanin, Z Krośniewic w powiecie kucieńskim, guberni warszawskiej, „Gazeta Świąteczna” 1895 , nr 737, s. 6.

${ }^{45}$ Gospodarze wsi Godowa, Z okolicy miasteczka Opola, „Gazeta Świąteczna” 1892, nr 615, s. 2.

${ }^{46}$ F.Z., Z Radomska w guberni piotrkowskiej, „Gazeta Świąteczna” 1897, nr 876, s. 6. s. 6.

47 Ł.O., Z Węgry w powiecie przasnyckim, guberni płockiej, "Gazeta Świąteczna” 1899, nr 991,

48 J. Nawrocki, Ze wsi Kamienia w powiecie augustowskim, guberni suwalskiej, „Gazeta Świąteczna" 1905, nr 1267, s. 6.

49 Zob. W.I. Thomas, F. Znaniecki, Chtop polski w Europie i Ameryce, t. IV, Warszawa 1976, s. 27-28. 
ci, które przychodzą na polską wieś wraz z modernizacją w drugiej połowie XIX w.

Przeprowadzone badania dają podstawę do mówienia o dominacji w wyobrażeniach społeczności wiejskiej pewnych wzorców charakterystycznych dla badanego okresu. Materiał źródłowy świadczy o tym, że pewne normy, obyczaje, reguły, wyobrażenia kształtujące w okresie od XVI do XVIII w. nadal zajmowały dominującą pozycję w umysłach ludności wiejskiej drugiej połowy XIX i początku XX w.

Ukształtowane wyobrażenia o kulturze szlacheckiej miały bezpośredni wpływ na sposób demonstracji sukcesu w środowisku wiejskim. Status społeczny podkreślano za pomocą rzeczy takich, jak: zegarek na łańcuchu lub parasol, kapelusz lub ilość zakładanych spódnic, poprzez spożywanie określonych produktów żywnościowych oraz alkohol. Podobne rodzaje własności socjologowie zaliczają do wtórnych. Nasilenie wykorzystania ich, jakie odnotowujemy $\mathrm{w}$ badanym okresie, następuje $\mathrm{w}$ momencie, kiedy aspiracje grupy społecznej mijają się z rzeczywistym stanem jej możliwości - brakiem ziemi, nieruchomości etc. 
Maria Krisań

\title{
Funkjonowanie pojęcia "pan" w kulturze wiejskiej Królestwa Polskiego końca XIX w.
}

\section{Streszczenie}

Celem artykułu jest próba rekonsktrukcji pojęcia „pan”, jakie ukształtowało się i funkcjonowało w wyobraźni środowiska wiejskiego pod koniec XIX w. Podstawą do badań są: listy chłopów-emigrantów do Brazylii i Stanów Zjednoczonych z lat 1890-1891, korespondencja ukazująca się na łamach czasopisma "Gazeta Świąteczna" wydawanego w Warszawie od 1881 r., pamiętniki chłopskie oraz dane etnograficzne zebrane na ziemiach Królestwa Polskiego na przełomie XIX-XX w.

\section{A Master in the Eyes of a Peasant in the Kingdom of Poland in the Second Half of the $19^{\text {th }}$ Century}

\begin{abstract}
The aim of the article is to reconstruct the notion of a "master", which was shaped and functioned in the minds of peasants in the end of the 19th century. The research is based on: letters of peasants who emigrated to Brazil and the USA from the years 1890-1891, letters published in "Gazeta Świąteczna" [The Holiday Gazette] published in Warsaw since 1881, peasants' diaries, and ethnography data collected in the Kingdom of Poland at the turn of the $20^{\text {th }}$ century.
\end{abstract}

